\title{
Use and safety of magnetic resonance imaging in patients with an implanted MRI-conditional pacing device
}

Maurits van der Graaf*, Pranav Bhagirath, Marco Götte

From 19th Annual SCMR Scientific Sessions

Los Angeles, CA, USA. 27-30 January 2016

\section{Background}

This study investigated the use and safety of Magnetic Resonance Imaging (MRI) for several pathologies in patients with an implanted MRI conditional pacing system.

\section{Methods}

This was a retrospective, single center study. All patients with an MRI conditional pacemaker or Internal Cardioverter Defibrillator (ICD) implanted in our center between

June 2011 and March 2015 were enrolled. All MRI examinations performed in these patients were evaluated. For all patients, pacing thresholds, P- and R-wave amplitude, lead impedance and battery longevity were monitored during the entire follow-up.

\section{Results}

In total, 214 patients with an implanted MRI conditional device (mean age $65 \pm 14 ; 64 \%$ male; 138 pacemakers; 76 ICDs) were enrolled. At the time of implant, $94 \%$ of these

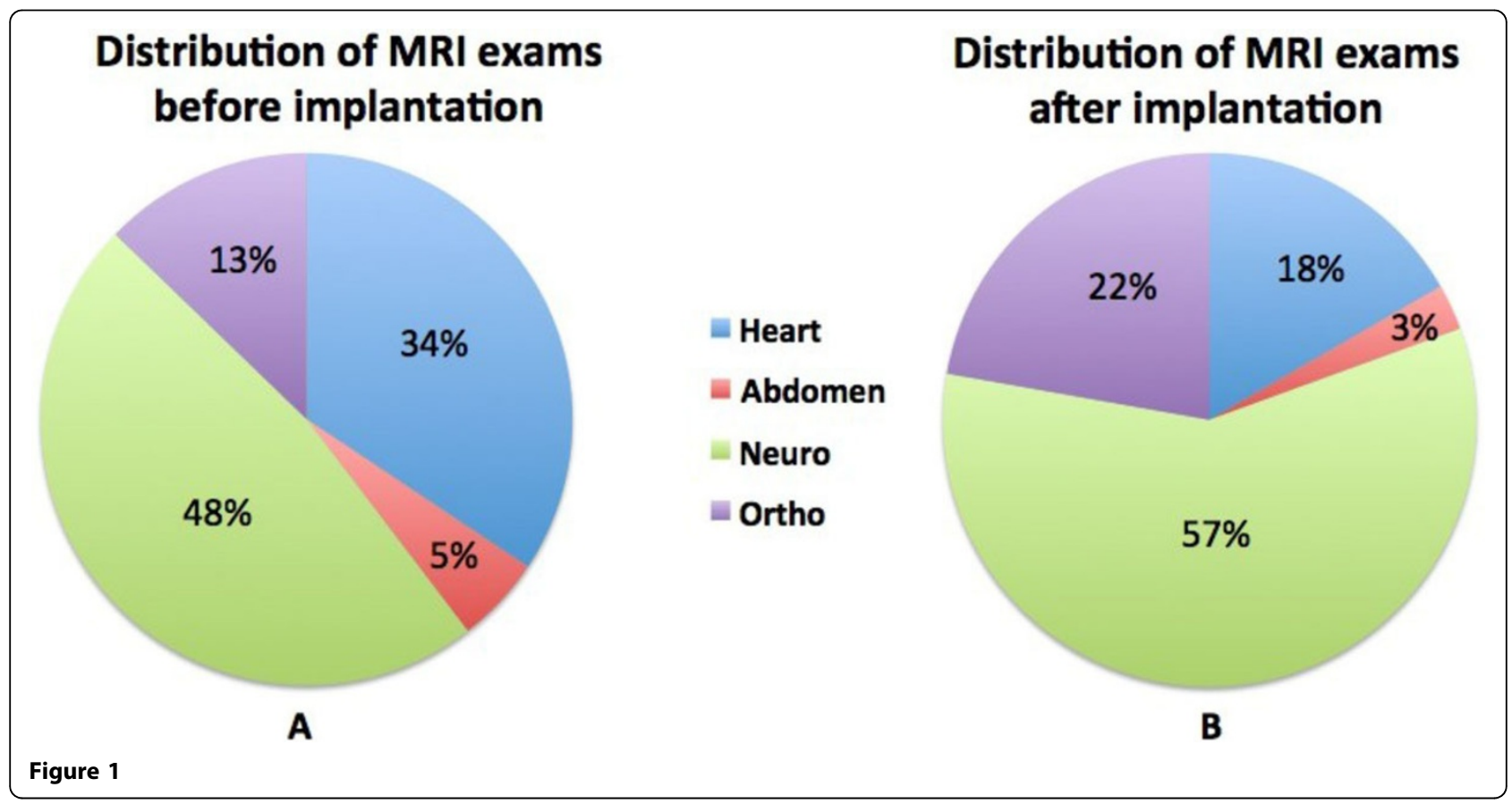

Cardiology, Haga Teaching Hospital, Den Haag, Netherlands

(c) 2016 van der Graaf et al. This is an Open Access article distributed under the terms of the Creative Commons Attribution License 
patients suffered from a co-morbidity that may lead to a future indication for MRI. In 24 patients (11\%), 36 MRI investigations were safely performed during a mean follow-up period of 406 days (51-1353 days). The majority of the scans were performed to confirm, exclude or followup on neurological disease (figure 1). There were no significant changes in lead impedance or sensing threshold between the pre- and post-procedural measurements.

\section{Conclusions}

Since MRI conditional devices are not yet available for all patients, patients that have a high likelihood of requiring an MRI examination in the near future need to be selected before implantation of these devices.

Published: 27 January 2016

doi:10.1186/1532-429X-18-S1-P199

Cite this article as: van der Graaf et al:: Use and safety of magnetic resonance imaging in patients with an implanted MRI-conditional pacing device. Journal of Cardiovascular Magnetic Resonance 2016 18(Suppl 1):P199.

Submit your next manuscript to BioMed Central and take full advantage of:

- Convenient online submission

- Thorough peer review

- No space constraints or color figure charges

- Immediate publication on acceptance

- Inclusion in PubMed, CAS, Scopus and Google Scholar

- Research which is freely available for redistribution

Submit your manuscript at www.biomedcentral.com/submit 